\title{
From the Archives
}

\section{Anthropological Responsibility in Nigeria ${ }^{1}$}

\author{
Onigu Otite
}

DOI: $10.36108 / \mathrm{NJSA} / 8002 / 60(0110)$

Vol. 6 Issue 1, 2008

\begin{abstract}
This paper participates in the crucial debate on the end of anthropology with particular reference to Nigeria. It takes the view that social anthropology predates colonialism which system nevertheless gave the discipline a slanted impetus of an exploitative and utilitarian nature. Under the colonial system, social anthropologists, mostly foreigners, were requested and/or funded to provide utilizable data on various indigenous systems in Nigeria. This led to a type of academic scramble in which social anthropological carved out "territories" for themselves through a glorification of the exclusive symbols and relationships which they found and through some grand theories based on these. The colonial indirect rule system tended to consolidate the sociocultural units marked out by these anthropological and quasi anthropological investigations. One major drawback of most of the early anthropological monographs in Nigeria is the general absence of the analysis of inter ethnic linkage relationships for clues to socio-cultural differences-reduction so that anthropology provides weak or no answer to the problem of increased ethnicity resulting from increased individual and group interaction in the emergent dynamic Nigerian society. This lack of knowledge of cultural and systemic convergence may, in part, be attributed to the theoretical orientation of social anthropology and to its preoccupation with smallscale and isolated total-system studies, presented in an ethnographic presence. Such anthropology and such theoretical kit and perspectives now have their limitations in any serious studies geared towards national integration and development. Thus, in order not to kill itself in Nigeria, social anthropology has to be macrosociological, refraining centrally from concern with some exotic micro-system or some zoo custom or joking relationship unless the relevance of this can be shown in the solutions to the problem of the Nigerian national political and economic development and integration. Formerly independent indigenous states and other anthropological preserves are now inescapably encapsulated as continuing but constrained systems in Nigeria. This continuing coexistence guarantees a place for social anthropology; the relevance of this place depends on anthropological contributions to national integration and to political and economic development.
\end{abstract}

Key words: anthropology, ethnicity, national integration, political development, Okpe

\footnotetext{
${ }^{1}$ Paper presented at the inaugural conference of NASA in Zaria, 16-18 December, 1971. The author was then a Senior Lecturer in the Department of Sociology at the University of Ibadan. The paper is being published as presented with minor editing.
} 


\section{Introduction}

If social anthropology is regarded as a child of imperialism and of colonial exploitation, either its life span must coincide with the period of colonialism, or it must modify itself to exist in a post-colonial period. If anthropology predates colonialism and was merely given a slanted impetus during the colonial regime, it must decline after the end of that regime and take new forms with the attainment of independence. Social anthropology may be defined simply as the study of networks of social relationships. Form its beginning, social anthropology has been problem-oriented: social reformation, transformation of the social order, social reconstruction, societal achievements, happiness of humanity, social development and materialistic preoccupations. Social anthropology may thus be regarded as a radical and utilitarian subject. Conceived of in this sense, it seems that we may say that social anthropology in Nigeria, as in those societies formerly under colonial rule, received impetus, exploitative impetus, as a discipline used and misused by the imperial powers as an aid to the colonial system. Thus rather than a child of imperialism (Gough, 1968) social anthropology was a tool of imperialism.

\section{The End of Social Anthropology?}

Some of the earliest works often found in Nigerian anthropological shelves include those by Basden, Meek, Partridge, Talbot and Temple; Bradbury, Bohannan, Fadipe, Forde, Jones, Lloyd and Smith. In one form or the other, these works fall within the mainstream of anthropology, dealing with selected variables in the societies studied. These works show typically that social anthropology has had its primary or sole concern with "holistic" study of societies. From this original standpoint, social anthropology now has to respond to socio-political change by modifying its methods, scope and theoretical perspectives. If it does this, it will overcome the shortcomings created by its own preoccupation with total-system studies and assert its responsibility in the analysis of current and future social relationships in Nigeria.

It was basically in consideration of the consequences of the incorporation processes involving anthropological preserves in new state social systems that Worsely (1966) and Hooker (1963) asked if social anthropological studies were not at an end. Hooker regarded anthropologists in Africa as "the handmaidens of colonial governments" producing essential knowledge of indigenous social systems, particularly those that cross the colonial artificial territorial boundaries, and concluded that "only in South Africa or Southern Rhodesia is the anthropologist likely to remain useful, but this usefulness is not consistent with self-respect, unless one seriously believes in the value of Bantustans." (1963:459). Few of the anthropological works in Nigeria, such as Smith (1960), avoided a synchronic-functional presentation, often in the ethnographic present, and a large number are static rather than processual, isolated rather than integrated, and micro- or mini-systemic rather than macrosystemic. Unless these various studies are brought up to date, they cannot, as 
they are, maximize their contribution to socio-political development in Nigeria nor can they raise any controversies of theoretical interest in the subject.

The opportunity for social anthropology to be involved in building up a development theory finds itself in the emerging but currently hybrid social systems in Nigeria and in other new states. Indeed, Worsley has warned that "Unless anthropology grapples with development evolution, it faces the fate of those animal species that became over-adapted to specialized environments." (1966:129). Also, as Onwuachi and Wolfe point out (1966:93), for anthropology to have a future in African states, it must involve itself in such problems as economic development, nation building, education and also national integration. If anthropology had been manipulated as a colonial exploitative tool in Nigeria, a new development-orientation of the discipline will ensure its relevant place in an independent Nigeria.

\section{Ethnicity and National Integration}

This orientation falls within the mainstream of anthropological thought and tradition, by providing relevant and consequential basic for national planning and development. One of the most important areas in the present and future Nigeria in which social anthropology has a responsibility is socio-cultural heterogeneity and the consequent problem of ethnicity. This problem is of practical interest and has repercussions for theoretical re-orientation since it takes anthropology out of its original preserves and pre-occupation with total systemic studies of isolated micro-worlds.

The problem of social anthropology is ethnic studies for Nigerian development does not lie mainly in the identification and often the anthropologist's glorification of "his" society. The problem lies in socio-cultural difference-reduction and the consequent promotion of national integration. The same colonial government processes that set up an emergent Nigerian social system also resulted in the consolidation of the various socio-cultural systems of the erstwhile kingdoms and indigenous states in the late 19th and early 20th centuries. These two processes, though apparently contradictory, were the practical results of the colonial "indirect rule" system, directed ultimately from Lagos.

This identification and the subsequent exclusively of ethnic systems were fanned by the insulated studies produced by social anthropologists in Nigeria, each carving a place and name for itself, but without the linkage relationships between their societies and other Nigerian societies. I regard this as a major drawback in most anthropological monographs concerning Nigeria. Their lack of the analysis, except in a negligible way, of the points of convergence between neighbouring indigenous systems as well as the linkages between the indigenous and new state systems resulted in the crucial absence of clues to ethnic and to socio-cultural difference-reduction. Consequently, each social group protects whatever excellent 'things' it has been said to have and ethnicity later increased when there was a greater degree of interaction between these consolidated groups and their leaders. 
Ethnicity itself is defined in terms of strife and discriminatory relationships between socio-cultural groups. Such groups are different in terms of more or less compulsory social institutions: religion, kinship, etc. At a lower level of abstraction there are indigenous state systems, which I say call submerged nations but which are often referred to as "tribes" in some anthropological literature. Such social units are often distinguished in terms of identifiable political and governmental institutions. Though both government and politics may be used as strong mechanisms for sustaining their exclusiveness, the cultural boundaries of those submerged nations, are not clear-cut.

Nigeria is thus a heterogeneous society because of its institutional differences shown by the over 250 incorporated diverse indigenous sociocultural units. As Kuper points out (1969:12) any institution has both its social and cultural aspects which do not necessarily coincide in coverage. These two aspects overlap just as societies overlap. Consequently, there are everywhere in Nigeria marginal social systemic analysis to explain these peripheral pockets of merging types of social relationships. I consider this to be one important rural focus of what anthropologists can do when studying convergence of social systems and institutions. Other examples of socio-cultural melting pots in Nigeria are the universities, the urban areas and industries where both formal and informal relationships that cut across ethnic boundaries are developed. By laying emphasis on such points that unite people, the problem of national integration will be made easier.

Anthropological contribution to economic development and the reduction of ethnicity can occur in the study of those people who are already involved in the production of cash crops or other commodities from expert or for industrial plants outside their territories. The task here is the undoing of cultural impediments in order to maximize production and to increase unrestricted participation in Nigerian economic development.

Perhaps the greatest contribution so far to our understanding of ethnic exclusiveness and indigenously organized trade and inter-dependence has been made by Cohen (1965, 1966 and 1969). He showed how the economic organization of Cattle and Kola in a long-distance trade, as well as religious symbolism have all been used as a means for creating and asserting Hausa Community (Sabo) separateness in Ibadan. These studies provide an analysis of the economic relations between the Yoruba and Hausa peoples and indicate areas of tension, which could be further analysed for indications to minimize ethnic rivalry. Also, in the same vein, Onoge's study of the Holy Apostles Community in Aiyetoro (1968) shows how some members of an ethnic group, that is, the Ilaje of the Yoruba, established their societal exclusiveness through religious symbolism and how this strong united base was maximized to achieve an unrivaled level of industrialisation and economic development in Okitipupa Division in the Western State of Nigeria.

Connected with this overall problem of economic development is the specific one of rural development. Most anthropologists working in the rural areas are apt to work as community development organizers, acting also as 
modernizing agents. Encouragement in production and the modernization of linkages and communication with other parts of Nigeria is a contribution to national integration at the grassroots level. Also anthropological findings can provide valuable information about modern economic opportunities and assets, which could prompt or increase the ruralization of industries. Such rural industrial set-ups could become centres for the integration of workers and dependants from various ethnic groups.

Thus, the anthropologist using his techniques and humble associations can discover or apply his knowledge to create various types and levels of alliances between ethnic groups on the one hand and between the indigenous societies and the new state social systems on the other hand. Cross-cutting alliances whether they are culturally based or whether they belong to the modern act of activities, produce crucial results such as inter-ethnic ties and communication, mutual understanding, common purpose and the involvement of members of one ethnic group in the affairs of the other. Such alliances generate mutual commitment and tend to minimize conflicts and tensions based on ethnic differences.

\section{Anthropological Study of Political Development: The Case of Okpe Kingdom}

Perhaps social and political anthropology makes its greatest contribution to national integration through its analysis of the political development of indigenous states and kingdoms and of other encapsulated systems in the new state. I undertook one such study in 1967 and 1968 and showed (see Otite, 1969), how an erstwhile independent state became part of the wider systems of Nigeria. I chose then chose Okpe, an Urhobo kingdom in Midwestern State of Nigeria, for my study and analysis. My study was in three main parts: the precolonial situation, the kingdom under a colonial rule and the kingdom in an independent Nigeria. I was particularly concerned with a detailed analysis of political institutional change under different situations, noting areas of continuity and change. My work involved a discussion of the encapsulating mechanisms of Nigeria and the vital problems of socio-cultural autonomy and dependence. I consider that this discussion can be generalized to cover other kingdoms or socio-cultural groupings in Nigeria.

That is, in all indigenous states in Nigeria we find traditional rulers and other leaders getting involved in various types of role performances and crosscutting participants. By these, they are involved in relationships with their neighbouring indigenous state systems and functionaries and with the new state systems and actors. Two arms of government were of particular importance in my study: the political and the administrative (I regard government as an inclusive concept involving four analytically distinct, but interdependent aspects: the political, the administrative, the judiciary and the executive). On the one hand, the administrative was incorporative and consolidating while utilizing the indigenous state systems and their principal actors. On the other hand, the political arm was more utilitarian in its relationship with indigenous 
state personnel, and was also factionalising in its effect on the indigenous social systems. To some extent, the political arm of government helped to break down ethnic barriers by cutting across ethnic boundaries and integrating sections of the various indigenous societies together through the various political party alliances and activities. Yet, political party leaders, once elected to parliament or to some political pressure group, did sometimes manipulate cultural symbols to whip up "tribal" or ethnic sentiments when involved in leadership and other contests.

In this kind of emergent hybrid social system, the indigenous principal actors, the king and the chiefs, relate their roles to their kingdom, to other Urhobo and non-Urhobo states and to the new state systems. Mutual benefits accrue from the recognition and utilization of indigenous state systems and their personnel. This live-and-let-live relationship between the new and the indigenous state systems and actors is a source of social and individual stability in Nigeria. It gives continuity to the less powerful and dependent indigenous social systems and provides opportunities for individual participants in various institutional spheres in the coexisting modern and traditional interactional sectors of the Nigerian society. Such recognition and utilization are carried to the highest state level at which principal political actors from the various sociocultural systems are together engaged in playing new roles in relation to the whole new state. Thus, such new state organs as the House of Chiefs and Statutory Corporations and Boards are integratory and melting centres for the different indigenous actors from diverse socio-cultural systems. Through such instrument as Declarations and Local Government Councils, the new state government interferes in the internal affairs of the various submerged nations and regulates succession to their key political positions. The end of such new state recognition and utilization of indigenous systems and personnel is not yet in sight, but anthropological analysis of the situation gives incisive insights into social integration and political development in Nigeria.

\section{Conclusion}

In order not to perish, social anthropology has to recognize the very dynamic and processual nature of the Nigerian society, and to change its scope and theoretical perspectives and preoccupations. Anthropological contribution in Nigeria and in other "developing" or "third world" countries cannot lie in the analysis of inconsequential and trivial relationships. Such would constitute academic trounce in the veil of some grand theory. My study of Okpe kingdom in modern Nigeria was a demonstration of this point. To some anthropologists, the work may appear unconventionally anthropological. Yet, I found it necessary and more useful to be macro-sociological rather than microsociological, by avoiding the typical, but not unrealistic holistic study of the kingdom, presented as if it were isolated from others. I showed the realism of the hybrid social system in Nigeria resulting from the coexistence and mutual reinforcement of the new state and the various indigenous social systems. My study suggests strongly that rather than approaching its end, social anthro- 
pology has a responsibility in the present and future studies of Nigeria and has important contributions to make to both practical knowledge and its utility and to the provision of a new body of data, which will lead to new theoretical formulations.

\section{References}

Basden, G.T. 1921. The Ibos of Nigeria. London: Seeley, Service and Co. Ltd. Basden, G.T. 1938. Niger Ibos. London: Seeley, Service and Co. Ltd.

Bohannan, L. \& Bohannan, P. 1953. The Tiv of Central Nigeria. London: International African Institute.

Boston, J.S. 1968. The Igala Kingdom. Ibadan: Oxford University Press.

Bradbury 1957. The Benin Kingdom and the Edo-Speaking Peoples of SouthWestern Nigeria. London: International African Institute.

Cohen, A. 1965. "The Social Organization of Credit in a West African Cattle Market." Africa, Vol. 25, No. 1.

Cohen, A. 1966. "Politics of the Kola Trade," pp. 18-36. Africa, Vol. 26 (1).

Cohen, A. 1969. Custom and Politics in Urban Africa. London: Routledge and Kegan Paul.

Dike, K.O. 1957. "The Benin Scheme Begins." In Corona, The Journal of Her Majesty's Overseas Service, Vol. IX, No. 9 pp. 325-328.

Forde, D. 1951. The Yoruba-Speaking Peoples of South-Western Nigeria. London: International African Institute.

Forde, D. 1964. Yako Studies. London: Oxford University Press.

Gough Kathleen 1968. "Anthropology: Child of Imperialism" Monthly Review. Vol. 19, No. 11 pp. 12-27 April 1968.

Green, M.M. 1964. Igbo Village Affairs. London: Frank Cass and Co. Ltd.

Hooker, J.R. 1963. "The Anthropologists' Frontier: The Last Phase of African Exploitation." The Journal of Modern African Studies 1, 4: pp. 455-459.

Kuper, L. 1969. "Plural Societies: Perspectives and Problems" pp. 7-26. in L. Kuper and M.G. Smith (eds.) Pluralism in Africa Berkeley and Los Angeles: University of California Press.

Jones, G.I. 1963. The Trading States of the Oil Rivers, London.

Lloyd 1957. "The Itsekiri" in Bradbury, The Benin Kingdom and the EdoSpeaking Peoples of South-Western Nigeria. London: International African Institute.

Lloyd, P.C. 1962. Yoruba Land Law. London: Oxford University Press.

Meek, C.K. 1931. Tribal Studies in Northern Nigeria. 2 Vols. London: Kegan Paul, Trench, Trubner and Co. Ltd.

Nadel, S.F. 1942. A Black Byzantium, the Kingdom of Nupe in Nigeria. London: Oxford University Press.

Okediji, F.O. \& Okediji, O. 1970. The Sociology of the Yoruba by N.A. Fadipe. Ibadan University Press. 
Onoge, O. 1968. Aiyetoro, The Successful Utopia: A Sociological Study of the Holy Apostles Community in Nigeria. Ph.D Thesis, Harvard University.

Onwuachi, P.C. \& Wolfe, A.W. 1966. "The Place of Anthropology in the Future of Africa" Human Organization, Vol. 25, No. 2.

Otite, K.J.O. 1969. The Political Organization of the Urhobos of the Midwestern State of Nigeria. Ph.D Thesis, University of London.

Partridge, C. 1905. Cross River Natives Being some Nites on the Primitive Pagans of Obubura Hill District, Southern Nigeria. London: Hutchinson.

Smith, M.G. 1960. Government in Zazzau 1800-1950. London: Oxford University Press.

Talbot, P.A. 1926. The Peoples of Southern Nigeria. 4 Volumes. London: Humphrey Milford, Oxford University Press.

Temple, C.L. (ed.) 1965. Notes on the Tribes, Provinces, Emirates and States of the Northern Provinces of Nigeria. London: Frank Cass and Co. Ltd.

Worsley, P. 1966. "The End of Anthropology?" in Transactions of the Sixth World Congress of Sociology. Vol. III pp. 121-129. 